DOI: $10.33067 /$ SE.2.2021.4

Mikotaj Rakusa-Suszczewski ${ }^{\star}$

\title{
Children as an Object of the Right-Wing Populist Politics and Discourse in Poland
}

\author{
Alons enfants de la Patrie \\ La Marseillaise \\ La Révolution dévore ses propres enfants \\ Danton
}

\begin{abstract}
In Central and Eastern Europe populist regimes are attracting attention as a result of the traumaticlegacy of communism, the subsequent overburdening reforms and exhausting systemic transformation, resurgence of ever-lurking nationalism, regional conservatism, parochialism and cultural chauvinism, and/or as an example of the structural shortcomings of young democracies at the borders of civilization. The subject literature also indicates numerous and universal elements of populist governments, present as well in this part of Europe. Without prejudging the aptness and strength of these various concepts and arguments, this article is an attempt to include in these wideranging themes a particular issue that absorbs conservative populists, namely "childhood" and "children". While the problem of children in politics has already received numerous interpretations, the importance of childhood in the right-wing populist discourse and politics has so far remained an issue discussed only occasionally. We put forward the thesis that children play an important and specific role in the right-wing populist superstructure - they constitute an illusory picture of the nation, an allegory of its renewal, as well as a convenient, though inconsistently used, instrument for achieving political, ideological and propaganda goals. Attitudes towards children can be an important characteristic of populism as such, and should be taken into account in research on the subject. We will illustrate these problems using the example of Poland and the populist Law and Justice (PiS) Party that is in power there now.
\end{abstract}

Keywords: Populism, Children, Biopolitics, Central Europe, Eastern Europe, Law and Justice, Poland

^ Mikołaj Rakusa-Suszczewski - University of Warsaw, e-mail: m.rakusasuszczewski@uw.edu.pl, ORCID: 0000-0003-0184-7839. 


\section{Introduction}

Some people believe that the so-called "world of children" exists in its biological dimension as a separate world unto itself. They interpret it either romantically as pure and innocent, or see uncouth and wayward creatures that need to be properly raised and trained. This latter view is how the pioneers of anthropology, such as Edward Burnett Taylor ${ }^{1}$ or John Lubbock ${ }^{2}$ perceived children. While interpreting the evolution of mankind and civilization, they compared children to exotic representatives of primitive peoples, i.e. as underaged, dependent, irrational and unproductive beings who should be kept at a safe distance from public affairs. The world of children should also be protected from its antithesis: a politics that appears to some as rational, and to others as a dirty profession and cynical sphere of competition and violence. In both cases, however, it is outside the domain of children. The adherents of this view maintain that while children are entitled to something like citizenship, they do not yet have the social and political subjectivity that would entitle them to any significant and substantial rights.

However, the very opposite claim with regard to "children's status" is just as common, and has become more and more popular since the fundamental ethnographic research of Margaret Mead and Ruth Benedict. ${ }^{3}$ On the basis of this alternative and the more socially-oriented paradigm, which breaks with the determinism of biology, the close relationship between the child and the world of politics and culture has always been part of the universal process of socialization, therefore building any age barriers - along with imaginary lines of what belongs to children and what belongs to the world of adults - is a more or less disguised form of discrimination, prejudice, and condescension. ${ }^{4}$ In the 1970 s, constructivism strengthened the thesis that "childhood" is a social phenomenon, created in a similar way as, for instance, the concept of "gender".

The competing points of view do not exclude the use of children as pawns, i.e. instrumentally, which has always been practiced in widelydiffering cultures and ideologies. Children's fate has often been considered

1 E.B. Taylor, Primitive Culture, London 1903, p. 7

2 J. Lubbock, The origin of civilisation and the primitive condition of Man, New York, Bombay and Calcutta 1912, p. 6.

3 M. Mead, Coming of Age in Samoa, New York 1928; R. Benedict, Continuities and discontinuities in cultural conditioning, "Psychiatry", no. I/1938, pp. 161-167, DOI: https://doi.org/10.1080/00332747.1938.11022182.

${ }_{4}$ The lack of such a distinction can be equally discriminatory, as illustrated by French historian Philippe Ariès in his book L'Enfant et la vie familiale sous l'Ancien Régime, Paris 1975, DOI: https://doi.org/10.2307/3319068. 
to be to fulfil the hopes for a better future, and their education brought with it promises of redemption for nations and cultures. With children in mind, revolutions were justified and great social and educational reforms were implemented, ideological fights were fought, political opponents were criticized for their use of children, and propaganda activities were carried out. In the name of God, natural rights, and tradition, but also in the name of the future utopias, their destiny has often been subjected to heavy trials involving indoctrination and lawlessness. In the principles of education, the rules of a patriotic education and other forms of broadly understood bildung, as well as in social programs aimed at children, faith in tradition was rebuilt and the most avant-garde visions of moral, social and political organization were spelled out. The innocence of children inspired the imagination of reformers and the fantasies of political extremists. Therefore, the discussion has always been about what could be gained or lost. Investments in childhood have usually made it difficult to see who children really are and what they really need, and carry the constant risk of their lives being instrumentalised by adults obsessed with distant, sometimes foggy and ill-considered, cultural and political ideals.

Political philosophy has usually treated children as a common good the property of the community (nation), and/or private (family) property, in both instances viewed as a blank slate that should be properly filled with the appropriate personality patterns and courses of action as the children develop. Different approaches - conservative rather than liberal ones appear quite frequently and freely in paternalist and populist practices all around Central and Eastern Europe, including Poland. Here we find numerous examples of actions, more or less intentional and deliberate, that affect children. Populists use them to antagonize society, fuel national myths, nourish panic and ideological disputes, as well as for propaganda purposes that delegitimize their perceived enemies.

\section{Children and the Logic of Antagonism}

The populist slogan "We must defend our children" is also one of those most oft-used phrases in Poland to stigmatize others. Here in Poland we can hear and read that children should be protected from and against: "gender sexualization", "leftist ideologies", "rainbow propaganda", "multiculturalism", etc. One can get the impression that the well-being and morality of children and families needs to be properly cared for in the context of a cultural conflict that threatens Polishness. On the other side of this dispute, we most often encounter the Western world, which is - in the interpretation of conservative populists - mainly a source of 
demoralization and collapse: full of "non-heteronormative degenerates" and "bizarre feminists" representing the "civilization of death"; as well as "paranoid terroecologists" who cynically exploit minors and sick children for their dirty business and heartless materialists and atheists who have renounced God: in a word - of a whole host of derailed liberals and leftists representing the "caste" and "salon" of the establishment.

Dividing people and introducing such vague and harmful distinctions belongs to the very essence of populist regimes and societies susceptible to their manipulation; regimes which polarise the world according to different criteria and at different levels, i.e. political: the democratic majority vs. the minority; social: the people vs. the elites; institutional: the corrupt vs. the honest; ontological: our own vs. foreign (the others); moral: good vs. bad; ideological: right vs. left; economic: poor vs. rich; religious: believers vs. godless atheists; racial: white vs. coloured; and even sexual: heterosexual vs. LGBTQ+. As emphasized by Mudde and Kaltwasser, separating people is a universal feature of the thin-centred ideology of populism. ${ }^{5}$ This "negative dialectic" allows populists to pursue a policy of simple and obvious solutions, in which there is no room for nuances. This is accompanied by the eternal risk of a xenophobic dislike, as well as anti-social practices of suspicion and innuendo, in line with the obsession that "other Satans are here at work". ${ }^{6}$ The simplicity of the images marked as the "axes of evil" is understood by the majority of citizens who, thanks to their recognition of them, can organize their experienced world and the external - more distant and abstract - one. 'Evil' thus comes to include the representatives of the judiciary who received their appointments during the communist era and those appointed by them; teachers who do not understand their educational mission; doctors incapable of disinterestedly curing ills; entrepreneurs enfranchised by social wealth; and journalists and intellectuals stung by a Hegelian bite. In short, these 'evil representatives' include the upper class of society and a large part of the upper middle class. Other bad or misguided structures include the European Union, which broke through the back door and instructs on how to behave; European powers that view new democracies condescendingly, shamelessly exploiting them for cheap labour and markets; globalization, enlightenment, immigration, etc. This means that at the root of any populism lies a hostility that always

5 C. Mudde, R.C. Kaltwasser, Working Paper: Voices Of The Peoples: Populism in Europe And Latin America Compared, 2011, https://kellogg.nd.edu/sites/default/files/ old_files/documents/378_0.pdf (access 5.02.2021).

${ }_{6}^{6}$ The words of the Polish writer Kornel Ujejski (1823-1897), used by Jarosław Kaczyński in one of his public statements. 
makes it revolutionary. As Ernesto Laclau states: "There is no populism without the discursive construction of an enemy: the ancient regime, the oligarchy, the Establishment, or whatever". This fabrication of the enemy, and not only in the discursive sense, organizes both the perceived harm and the resentment of the excluded, as well as the worldview of those increasingly lost in a world where "all that is solid melts into the air". This strategic procedure creates a feeling of constant threat and uncertainty and mobilizes the readiness of the 'masses' to confront, clash, and fight.

Children play a special role in this politics of antagonism. It is through them that an innocent adversary becomes a potentially deadly and evil enemy. In the language of bio-populism, children constitute the "body" of the people, the essence of what is potentially the best and healthiest. Everything that threatens them is the worst. Polish Prime Minister Mateusz Morawiecki offered such a vision in his exposé: "«Such will be the Commonwealth as their youth will be kept». ${ }^{8}$ It is our children and grandchildren who will build the Poland we miss." Children are the folk idealization of the nation - the embodiment of the innocent and the honest, but also the harmed, marginalized and poor, who preserve the noblest virtues and almost the truth itself. In the social imaginaries, they always embody infinite opportunities, open possibilities, and hopes for self-fulfilment. This has obvious consequences: crimes against children take on an additional dimension and meaning. Rape inflicted on the youngest is a violence against the nation and its moral and spiritual future. The images of threats faced by the children, fuelled by the authorities, apply equally to the entire 'great national family'.

In this article I put forward the thesis that in this populist policy of antagonisms, childhood issues and problems are instrumentally used in government policy, which in practice means either disregard for them or excessive interference with their autonomy. You can see this phenomenon in, inter alia, the increasing focus on the threats to which children are allegedly exposed. This kind of action is expressed in two ways: 1) by diagnosing the threats and offering 'help'; and 2) by tightening the law, not only in connection with the direct physical violence against children, but also against the lurking social and symbolic violence, most often defined as "depravation". The elusive nature of this symbolic violence allows it to be manipulated quite freely; either exaggerated or diminished.

${ }^{7}$ E. Laclau, Populism: What's in a Name?, in: Populism and the Mirror of Democracy, ed. F. Panizza, London 2005, p. 39.

8 Words of Jan Zamojski (1546-1605), written in 1600 on the occasion of the opening of the Zamoyski Academy. 
I will show that this also applies to direct crimes against children, which are sometimes ignored and sometimes exaggerated. ${ }^{9}$

In the program declaration of the ruling PiS party, we find: "The spread of gender ideology is dangerous for the family and for parenthood in Poland; (...) Establishing barriers to the spread of gender ideology is important (...)"; 10 "The institutions of the Polish state have begun to effectively defend Polish families and children living outside Poland against unfair decisions made by the authorities of their state of residence, e.g. Germany, Norway". ${ }^{11}$ And finally: "We will effectively support families in a social, material and legal sense; protect their autonomy from ideological offensives; and take actions against domestic violence. We will not replace parents in freely shaping their child's development. PiS will oppose any attacks on the family, which figures in the constitution as the subject of special state protection". ${ }^{12}$ Thus we read in the party's program about various external threats, resulting from, among others, the policy of equality, known in Poland as "gender ideology", or the allegedly antiPolish activities of supervision institutions in some Western countries. This gives the impression of an organized activity consciously directed against Polish children, which is an obvious abuse, because the activity of the Jugendamts in Germany and Austria or the Barnevernets in Norway - to which allusions are made - although they may be controversial, also include non-Polish families under the same supervision. In PiS's program, the authority of the family is unconditionally placed on a pedestal, which creates a false image of children who belong exclusively to their families, although it is obvious that parents protect their children primarily in accordance with applicable law, accepted norms and social obligations. At the same time, as it is clear from the cited declarations that politicians themselves wish to decide what constitutes an "attack" on the family.

Economic arguments are repeatedly formulated about neglected children, living below the poverty line or unfairly taken over by the state because of their hardships. The impression is created that the wealth of some is gained at the expense of the weak and the poor, and especially against their children. Ex-Prime Minister Beata Szydło stated in her exposé: "Poles often say that the Polish justice system is not fair. It is not fair to those who are weaker, who are poor, (...) isn't it a shame for the Polish state, for all of us, that today in Poland parents are taken from their

9 M. Szafrańska, Penalny populizm a media, Kraków 2015.

10 Program Prawa i Sprawiedliwości, Polski Model Państwa Dobrobytu, 2019, p. 11, http://pis.org.pl/files/Program_PIS_2019.pdf (access 5.02.2021).

11 Ibidem, p. 175.

12 Ibidem, p. 219. 
children only because the family has a low income? Isn't that our shame? You don't want to see it! We have seen it and we will change it". ${ }^{13}$ The Prime Minister's speech combines poverty and injustice with its criticism of the political elite. The image of hungry children being taken over by officials is a propaganda ploy used against the political opposition.

This sense of danger is built in connection with the defence of the conceived life. The issue of tightening the abortion law returns regularly, both under pressure from the Polish Church and under civic initiatives. It has been ruled on in court and/or parliament at least three times during PiS rule. First it led to massive demonstrations and the so-called "black umbrellas" protest in 2017; the second time the case returned to Parliament in the context of the "Stop the abortion!" project, initiated by the Życie $i$ Rodzina (Life and Family) Foundation - a pro-life organization that actively fights against the LGBT + community. In the third instance this problem returned with great force following the handing down of a decision by the Polish Constitutional Tribunal, which ruled that the right to obtain an abortion in cases of severe and irreversible damage to the foetus was inconsistent with the Polish Constitution, and thus arbitrarily ended the so-called "abortion compromise" in force in Poland since 1993.

In this regard, many populist forces directly refer to the Christian tradition and the stances of the Catholic Church. This strategy contains as much authenticity as pure opportunism and cynicism, because the support of such a significant institution as the Church constitutes invaluable capital for any political party, particularly in Poland. Moreover, in strongly religious societies populist Manichaeism falls on fertile ground, because by nature national populists, like most religious people, see the world in black and white terms. In populist language, the fate of children is alltoo-often determined by anti-Christian ideologies, the "civilization of death", permissive liberalism, cosmopolitism, consumerism, hedonism, materialism, and so on. In short, children are threatened by a sick culture that has renounced its own roots. The political leader of the Law and Justice party - Jarosław Kaczyński - is convinced that there are deliberate attempts to destroy Christianity, European culture, and the family, and that “(...) there is an attempt to create such a world in which, in fact, nothing is certain; there is no identity, even the most elementary identities do not exist". ${ }^{14}$ Such apocalyptic claims belong to classical repertoire of populist statements.

13 Exposé of Prime Minister Beata Szydło of 2015, https://www.gov.pl/web/premier/stenogram-expos-premier-beaty-szydlo (access 1.04.2021).

${ }^{14}$ Interview with J. Kaczyński: Kaczyński: Polska minus? Będzie się demoralizowato dzieci, https://www.rp.pl/LGBT/191009763-Kaczynski-Polska-minus-Bedzie-sie-demoralizowalo-dzieci.html (access 5.02.2021). 
Children, being in fact the most vulnerable and helpless, are constantly present and even over-represented in populist rhetoric and actions. It can be said that by using children as political tools, populists want to play the role of caring parents and guardians of the nation, that ruthlessly fight against the violence and evil. They claim to be able to see and perceive the most important problems fully and totally, the ignored dimensions of harm - innocent victims of neglect and injustice. Populists therefore insist on tougher laws on offenses and crimes to fight against those who evade their maintenance/support obligations, paedophiles, irreversible degenerates and child killers, be it on account of child pornography, abduction, or demoralization. In May 2019, the Minister of Justice, Zbigniew Ziobro, presented plans to tighten the criminal law, especially with regard to sexual offenses. The project proposed, inter alia, increasing the age of the legal and criminal protection of children from 15 to 16; increasing the penalty for rape on a minor from 15 to 30 years of imprisonment; an annuity for the death of a child as a result of rape; abolishing the statute of limitations for the crime of rape; extending the information contained in the register of paedophiles, etc. While this direction in the tightening of the law is overall appreciated and approved by the majority of Poles, the greatest controversy accompanies the proposed citizenship act, which provides penalties for so-called "praising sexual intercourse". ${ }^{15}$ This fuzzy bill that may, for example stigmatize teachers, is clearly a defensive reaction to the guidelines of the World Health Organization regarding the standards for sexual education for children. In general, we are dealing here in principle with moral verdicts rather than with a prophylaxis of solving children's problems, and therefore with rather theoretical and 'show' acts of indignation calculated for ideological fights, with children in the background rather than reflecting a genuine concern for their lives.

\section{Child Rights and National Obsessions}

The fact that right-wing populism in Central and Eastern Europe was developed in open confrontation with liberal and constitutional democracy is quite widely-recognized today in the subject literature. ${ }^{16}$

15 The draft amendment to the Penal Code, in the drafting process since October 2019, entitled "Stop Pedophilia" was submitted by the Pro - Prawo do do Życia (ProLife) Foundation.

16 V. Tismăneanu, Fantasies of Salvation: Democracy, Nationalism and Myth in Post-Communist Europe, Princeton 1998; DOI: https://doi.org/10.1016/j. postcomstud.2008.03.006; C. Mudde, The Populist Zeitgeist, "Government and Opposition”, no. 39(4)/2004, pp. 541-563; DOI: https://doi.org/10.1111/j.1477-7053 .2004.00135.x; B. Bugaric, Populism, Liberal Democracy, and the Rule of Law in Cen- 
Some populist politicians, such as Victor Orban or Jarosław Kaczyński, openly emphasize the need to create a non-liberal or illiberal form of an allegedly communal alternative, for example under the slogan of the "Polish model of the welfare state". An interesting question dividing theorists is whether populism is therefore a pathology, a correction, or the essence of democracy ${ }^{17}$ Violating the constitution and a disregard for international obligations and human rights are certainly a threat to liberal democracy and an aberration and pathology, but social practices incorporating citizens, e.g. by including them in the stream of politics and the economy, in the name of the ever-popular bourgeois revolution slogan "We, the people" doesn't necessarily fall in to this category.

According to the classical concept of democracy, winning elections gives rise to unlimited authority to decide about the state. This is how the right-wing populists usually wish to understand democracy: as the ultimate right of the majority to exercise power, independently from any obligations resulting from universal human rights, or the rules of the balance of power. In other words, they deliberately undermine the order of liberal democracies. It must be made very clear that populist regimes in Eastern Europe, such as the PiS party in Poland, benefit from this ambiguity (democracy versus liberal democracy). They define their "truly democratic" form of political community in terms of national identity, which creates a dangerous temptation to apply the law one way to "their own" and differently to the so-called "aliens". This chauvinistic logic is sometimes applied not only to foreigners, but also to anyone who could be arbitrarily considered as foreign to the national representation. The concept of a "traitor to the nation" and other excluding terms and invectives are obsessively repeated in Poland every day. Children are also affected by the problem of exclusion.

In liberal democratic states, the issue of child rights emerged relatively recently. In John Rawls's Theory of Fustice, a work that discusses the rules of an impartial social contract with unprecedented meticulousness, the issue of children as potential participants in a so-called "contract behind

tral and Eastern Europe, "Communist and Post-Communist Studies", no. 41(2)/2008, pp. 191-203, DOI: https://doi.org/10.1016/j.postcomstud.2008.03.006.

17 P. Taggart, Populism and the pathology of representative politics, in: Democracies and the populist challenge, eds. Y. Mény, Y. Surel, Basingstoke 2002, pp. 62-80, DOI: https:// doi.org/10.1057/9781403920072_4; T. Akkerman, Populism and Democracy: Challenge or Pathology, "Acta Politica”, no. 38/2003, pp. 147-159; DOI: https://doi.org/10.1057/ palgrave.ap.5500021; Y. Mény, Y. Surel, The Constitutive Ambiguity of Populism, in: Democracies and the Populist Challenge, eds. Y. Mény, Y. Surel, London 2002; P. Dejneka, Populizm a sfera publiczna. Czy populizm zrewitalizuje sfere publiczna w Europie, Warszawa 2019, DOI: https://doi.org/10.1057/9781403920072_1. 
the veil of ignorance" establishing the principles of a fair state is discussed as if the lack of their moral and civic competences were obvious. ${ }^{18}$ From the beginning of the 1970 s, one can speak of a breakthrough related to the development of social constructivism and attempts to empower children. ${ }^{19}$ The need to take them into account has become more and more often considered, and children's rights have begun to ever more absorb the imagination of politicians and the public. At the same time, the concept of democratic representation began to be redefined, sometimes the electoral age was lowered, looking for ways to include young people in social communication and emphasizing the importance of participation, creating children's parliaments and other representations in important state institutions. The areas of children's political activity have become an element of research for good. ${ }^{20}$ As Kallio and Häkli claim: “(...) children engage in various kinds of politics in which they have their own positions and roles - politics which cannot be known before children's quotidian lives are studied as potentially political" ${ }^{21}$

Right-wing populism, on the other hand, resists these tendencies to empower children and calls for moral conservatism - strengthening the role of the family/parents and school (state) in the educational process, stopping the liberalization and social emancipation, which are seen as sources of disintegration of the national identity and the causes behind the breakdown of all interpersonal and intergenerational relationships. Paternalistic power is treated as a good in itself, almost analogously to government power exercised over the nation in the public sphere, or church power exercised in the moral and metaphysical dimension. As a result, the PiS government's political priority is to include schools more and more in memory politics, as well as moral and patriotic education. Young people are expected to have "greater political awareness", which is usually understood as being critical of the liberal human rights' ethics and other

${ }_{18}$ J. Rawls, Theory of Justice (revised edition), Cambridge MA. 1999, p. 397-449.

19 J. La Fontaine, An anthropological perspective on children, in: Children of Social Worlds, eds. M. Richards, P. Light, Cambridge 1986.

20 E. Such, R. Walker, Young citizens or policy objects? Children in the 'rights and responsibilities' debate, “Journal of Social Policy”, no. 34(1)/2005, pp. 39-57, DOI: https://doi.org/10.1017/S0047279404008256; S. White, S. Choudhury, The politics of child participation in international development: the dilemma of agency, "The European Journal of Development Research", no. 19(4)/2007, pp. 529-550, DOI: https://doi. org/10.1080/09578810701667508; T. Skelton, Taking young people as political actors seriously: opening the borders of political geography, "Area”, no. 42/2010, pp. 145-151, DOI: https://doi.org/10.1111/j.1475-4762.2009.00891.x.

21 K.P. Kallio, J. Häkli, Are There Politics in Childhood?, "Space and Polity", no. 15(1)/2011, p. 22, DOI: https://doi.org/10.1080/13562576.2011.567897. 
forms of universalism. Encouraging fuzzy communitarian feelings is not even a plausible way to educate children about patriotism and responsible citizenship. On the other hand, this form of education can foster crowds of "other-directed personalities", and in the future also authoritarian citizens mindlessly stigmatizing all diversity. Paradoxically, we are dealing in Poland with a recidivism of authoritarianism, characteristic of the communist era.

In the case of Poland however, the consequences of such ideologization, laced with nationalistic obsessions, are unfortunately much more tangible. For example, the state restricts the possibilities of protecting children in accordance with the postulates of the Convention on the Rights of the Child. Poland has so far not ratified the 3rd Optional Protocol to the Convention on the Rights of the Child, which gives the UN Committee on the Rights of the Child the competence to receive and recognize individual notifications of violations of children's rights. The ambiguous viewpoint about children's rights, and thus their subjective treatment, is clearly visible for example in the way of thinking of the new Polish Ombudsman for Children, Mikołaj Pawlak, ${ }^{22}$ who indeed discusses the rights of children, but primarily of the unborn (i.e. in the context of prohibiting abortions). With regard to a child's right to a complete education (including, until recently, obligatory sex education classes), he stresses that such classes constitute a threat to family autonomy and can potentially leads to demoralisation; and when it comes to the situation of children of non-heteronormative parents, he consistently emphasizes that these children are exposed to the dangers of harmful ideologies. One example is the dispute over the transcription of a foreign birth certificate of a child whose parents are of the same sex. In Poland, the lack of such a possibility violates the Polish Citizenship Act, the European Convention on Human Rights, and the Convention on the Rights of the Child. The case could probably be clarified on the basis of the existing law if it were not politicized through the direct involvement of the Minister of Justice and the General Prosecutor, who openly argue that such a refusal is consistent with Polish law. Ultimately, the Supreme Administrative Court upheld the ban, although it also ordered the issuance of an identification number to the child, which is necessary to obtain citizenship.

Children are often included in cultural disputes that accompany ethnically diverse countries ruled by right-wing populists. Such controversies have recently been aggravated due to the 2015 immigration crisis, which

${ }_{22}$ M. Dagiel, M. Kowalik-Olubińska, Bycie dziecka w Polsce „dobrej zmiany”- między Konwencja o Prawach Dziecka a rzeczywistościq, "Problemy Wczesnej Edukacji”, no. 4(43)/2018, pp. 114-124, DOI: https://doi.org/10.26881/pwe.2018.43.11. 
has put human rights policy to the test. In Central and Eastern Europe, for example, the integration (or actually non-integration) of Roma children is a constant and recurring problem. The Roma minority in many countries in this part of Europe (Romania, Bulgaria or Hungary) are considered to be the source of genuine social problems: in particular crimes and unemployment. But the way chosen to resolve these issues usually consists of stigmatizing this minority and threatening its extensive growth, as well as playing on numerous unjustified and unfair stereotypes. ${ }^{23}$ Like other minorities, the Roma play the role of the scapegoat - the alleged cause of all kinds of evils and pathologies. Their condemnation belongs thus to the classical repertoire of populist racism and discrimination. For example, it is quite common to segregate Roma children in special schools, under the pretext of addressing their "peculiar" lifestyle and "maladjustment", as takes place in the Czech Republic, Slovakia, Romania, and Croatia. ${ }^{24}$ In the populists' language, Roma citizens constitute a culturally-alien and difficult to supervise "factor".

Negative attitude towards immigrants is also a common phenomenon in this part of Europe, which results from numerous historical, social, and structural conditions, as well as from $a d$ hoc populist policies. It is quite difficult thus to judge whether the government is acting realistically and simply takes into account the prevailing public opinion, or whether it instrumentally misuses and abuses the public's stereotypes and fears. In either case however, these actions do not give either immigrants or the societies the chance for a more civilized, morally mature and empathic view of reality. Children, who make up a large proportion of the immigrant population, are also direct victims of this xenophobic immigration policy. Numerous problems of children's rights in this regard were already noted by the previous Ombudsman for child rights in Poland, Marek Michalak in his letter to the Prime Minister. ${ }^{25}$ For example, he pointed out the insufficient protection of children at the state borders, the violation of the provisions of the Geneva Convention, and/or the unjustified and

23 Cf. M. Stewart, The Gypsy 'menace': Populism and the New Anti-Gypsy Politics, London 2012; Populism, Memory and Minority Rights: Central Eastern European Issues in Global Perspective, ed. A.-M. Bíró, Boston 2018, DOI: https://doi. org/10.1163/9789004386426.

24 Cf. M. Billout, Rapport d'information fait au nom de la commission des affaires européennes sur l'intégration des roms: un défi pour l'union européenne et ses états membres, 2012, https://www.senat.fr/rap/r12-199/r12-199_mono.html; Amnesty International, Portes ouvertes sur l'avenir. Non à la ségrégation dés enfants Roms dans les écoles slovaques, 2010, https:/www.amnesty.org/download/Documents/EUR720042010FRENCH. PDF (access 8.02.2021).

25 M. Michalak, Letter to Prime Minister, 2018. Document nr GA8.422.10.2018.BS. 
prolonged detention of minor foreigners. The situation has not changed in this respect. According to the reports of the Association for Legal Intervention [Polish: Stowarzyszenie Interwencji Prawnej], children's centres constitute about a quarter of all closed detention centres. Children are also increasingly victims of racist violence, which can also be seen as a consequence of anti-immigrant sentiments either fuelled by, or at least downplayed by the authorities. The increasing problems of racism and discrimination against children did not go unnoticed by the aforementioned Ombudsman, who in 2018 - after three years of rule by the PiS - pointed out that: "(...) attacks based on discrimination are taking place more and more often in Poland, and these attacks are not only offensive words addressed to foreigners or people who communicate in foreign languages, but often turn into physical aggression, in extreme cases even towards children". ${ }^{26}$

Discrimination based on ethnic, religious, or national origins is particularly striking in the context of the objections made by Polish Government to the European Commission against such states as the United Kingdom, Germany or Austria - which have considered limiting social support to workers whose children live outside the borders of their country (kindergeld). Such plans were outlined in December 2017 by Sebastian Kurz from the conservative Austrian People's Party (OeVP), while in Germany a similar initiative was launched in 2016 by the thenSPD politician and economy minister Sigmar Gabriel, and in the UK by David Cameron. These initiatives were mainly directed at employees from Central and Eastern Europe. It is certainly a good thing that the Polish government cares about the interests of Polish children, but this policy should also apply to all including immigrant children in the country and should be in accordance with EU equality standards.

\section{Gender, Family and Moral Panic}

Caring for children is a natural and biologically conditioned reflex of parents, therefore exploiting it is almost subliminal, and it certainly works on atavistic protective instincts. Additionally, increased concern for the safety of children is almost a sign of our times and a reflection of cultural changes. The development of new technologies, liberalization, globalization, and other cultural challenges simultaneously increase the need for parental control, as well as give rise to numerous obsessions and

${ }^{26}$ M. Michalak, Ibidem, Postawy rasistowskie i ksenofobiczne się nasilają. Jak temu przeciwdziałać? Rzecznik pisze do premiera Morawieckiego i ministra Ziobry. Document nr XI.518.5.2018. 
the anxiety of overprotection. In many countries of the region, including in Poland, this goes hand-in-hand with the belief, expressed for many years, that family happiness is, next to health, the most important value. Some populist regimes use all these factors in their activities, highlighting the importance of family and health policy. This tendency certainly underpins numerous and often useful social programs, yet concerns are being raised that the modernization is a source of degenerative cultural changes, a threat to the safety, happiness, and health of families and children. As a result, conservative populism, with its hysterical and indignant reactions to everything new and different, preys on backwardness, psychosis, and confusion, and contributes to moral panic.

The problems associated with traditional gender divisions and the stigmatization of alternative family models (informal, cohabitation, blended families, etc.), and especially concerns about homosexual partnerships, are exploited almost obsessively by most conservative and populist politicians, who view them as an example of the demoralization and ideological distortion of European culture. An equally rigid and fearmongering stance is formulated with regard to the sexual education of children, which is constantly seen as a conspiratorial operation of leftist circles. In November 2019, Prime Minister Morawiecki emphasized in his exposé that the family should be "untouchable", and whoever raises an "ideological hand" on this "arch-Polish value" raises it on the entire Polish community. The reaction of Jarosław Kaczyński to the standards of sex education in Europe recommended by the WHO, as well as to the Warsaw declaration for the LGBT + community, is also very telling. The PiS leader said: "As we know, it is about sexualization of children from an early age. We have to fight it. We must defend the Polish family. We have to defend the Polish family with full determination, and even with ferocity, because this is a civilizational threat, not only for Poland, but for the whole of Europe, and for the whole civilization that was created on the basis of Christianity". ${ }^{27}$ It should be added that, as a consequence, a number of local governments in Poland came up with the idea of socalled "LGBT-free zones", which provoked the protests of many countries and even the severance of relations on the part of some partner cities. ${ }^{28}$

Although such declarations may be underpinned by Christian worldviews and express concern for the traditional family model, they also violate modern standards of freedom and equality, as well as discriminate

${ }^{27}$ https://wpolityce.pl/polityka/439323-prezes-pis-trzeba-bronic-polskiej-rodziny (access 5.02.2021).

28 This applies, for example, to the Dutch city of Nieuwegein and the French Douai towards Puławy, or the French Saint-Jean-de-Braye towards Tuchów. 
against non-heteronormative families and children. This is an expression not only of a lack of sensitivity, but of the infliction of a mindless harm on the weakest, who have to bear the consequences of the rulers' ideological ploys, games and obsessions. The so-called "LGBT ideology" (whatever that means) was the leitmotif of the presidential campaign (successful) of Andrzej Duda, who emphasized at every step that in this debate we are dealing not so much with specific people with different sexual orientations, but with an aggressive ideology imposed on Polish citizens in an analogous way to Bolshevism.

Ideological thinking, moral conservatism, or the misuse of religious ethics by the authorities appears not only in the form of open aversion to LGBT communities, but also hits other aspects of the physical existence of citizens. In June 2016, the Polish government withdrew from programs for co-financing IVF treatments, and in July 2017 it also introduced prescriptions for contraceptives, including emergency contraceptive pills. Some representatives of the ruling party pointed to the physical handicaps of children born through in vitro fertilization, contributing to their stigmatization. In 2016, the postulates of tightening the abortion law and banning abortion for both raped women and those whose unborn children are burdened with serious genetic defects (the socalled eugenic abortion) returned. An argument was put forward that the tightening of abortion regulations was supposed to express the right to life of unborn children, and thus express innate and inalienable human rights. This discussion caused numerous controversies and social unrest - in particular the so-called "black protest" in 2017. ${ }^{29}$ In October 2020, following the decision of the Constitutional Tribunal of the Republic of Poland banning abortions for mothers with unborn children with fatal foetus defects (FFAs), the largest protests in free Poland since 1989 swept across the country under the slogan of "Women's Strike". The problem of reproductive justice and women's rights has made children indirectly a central element of populist biopolitics and the subject of an ideological dispute. Ironically, the mass mobilization of the youngest citizens in 2020 is a deeply moving and symbolic protest against the continuing policy of treating children instrumentally. Many commentators in Poland believe that the protests herald the end of Law and Justice's rule, or even the end of a whole generation of politicians - "satraps" and "grandpops".

The reactions of populist parties in Central and Eastern Europe to the Convention on preventing and combating violence against women and domestic violence (the so-called Istambul Convention) are also quite

${ }^{29}$ Bunt kobiet. Czarne Protesty i Strajki Kobiet, eds. E. Korolczuk et al., Gdańsk 2018. 
significant. Plans to withdraw from the agreement have been declared by the PiS party since 2012, when the Convention was ratified by Poland. The President of Poland, Andrzej Duda, described this document as "dangerous" and "perfidious", as well as "inconsistent with common sense"; ex-prime Minister Beata Szydło said that the Convention was a "hoax"; the current Minister of Justice stated that "this is a feminist product that is supposed to justify the gay ideology"; and in 2020 Deputy Minister of Justice Marcin Romanowski called the Convention "gender gibberish". While in the end the Convention was not terminated, Amnesty International observers emphasize that the document remains a "dead letter", referring to the fact that the provisions necessary to enforce it have not been included in the penal code nor in any anti-discriminatory prevention measures.

The activities of PiS are part of the opposition to the mainstream gender policy. However, what is most striking is the lack of interest in the children themselves, who are one of the main targeted recipients of the benefits of the Convention. In Poland, the previous Ombudsman for Children also pointed to the neglect in creating a comprehensive strategy to combat violence against children, going beyond the so-called 'family violence' regulated by the archaic Polish Family and Guardianship Code. In this regard, we find ourselves again with a mix of traditionalism and populism that follows well-established patterns of thinking and behaviour that ignore the interests of children. In Poland this is visible especially in the discussion on so-called "spanking" and the attempts to downplay or relativize this form of calling children to order by distinguishing it from "beating"; in other words disregarding the problem and allowing "milder" acts of violence against them. This is a striking inconsistency by a cynical power that instrumentally uses children in its ideological struggles.

\section{Ideologies and Children's Education}

We can find a mixture of different ideologies concerning education and the upbringing of children in populist regimes. There are two main forms of populism that are of interest in this context. The first treats populism as a simplified, thin-centred ideology based on a dualistic world view, whereby the popular class acts against the corrupt and vicious elites in name of the sovereign nation and the inclusion of the "marginalised majority". Sometimes this way of thinking is based on the so-called "political realism", which refers to historical and cultural necessity and allegedly morally justified - paths of retaliation and redress. The second 
form is the so-called "empty populism", a tactic or form of political manipulation designed only for short-term success, not for long-term moral goals. Such a populism is devoid of content, however it freely uses other ideologies to justify its own actions and give them a deeper meaning and seriousness. In the case of the right-wing populism which dominates in Central and Eastern Europe, we find a conjunctive combination of both these forms of populism within the framework of vulgarized forms of conservatism, nationalism, and religious ethics. These ideological aspects have a fundamental influence on the shape and course of the reform of children's education.

A widespread belief exists amongst populist conservative circles that Polish children have been badly brought up so far. ${ }^{30}$ Children and adolescents today are allegedly idle, superstitious, devoid of ambition, and effeminate. The existing forms of primary and higher education and the general directions of the so-called "critical education" (liberal) are questioned. Right-wing social pedagogy is primarily about creating and strengthening a healthy scepticism towards all those novelties which require overcoming traditional attitudes. Modernity and globalization are a source of fundamental problems for right-wing populists, whose alleged 'moral compasses' point to avoidance of anything that is foreign and new. However, instead of arousing constructive criticism, this project may generate retrograde prejudices among children. Saturated with resentment and a sense of injustice, full of anachronistic ideas about social life and exaggerated and distorted stories woven from national myths, this project will only deepen the very sense of provincialism and loneliness that the Polish right is trying to fight against.

There are numerous examples of moralizing politics, permeated with extreme megalomania, national haughtiness, intolerance, and illustrious romanticism. The new patriotic upbringing of children, which focuses on heroism and martyrdom, fuels a national sense of superiority and a combative attitude towards everything that is foreign. It shows how important children are as an element of the anti-liberal agenda of social reeducation, and how instrumentally they can be treated in this "mission". Politicians seem to assume that children should be filled with a national content in order to create a "new man", disregarding his (or her) real needs and expectations. Finally, it must be added that the mere critical assessment of the shape of civic education in the last two decades, and the obsession with the alleged permissiveness at schools, has not turned into any meaningful and convincing education project capable of dealing

${ }^{30}$ T. Tokarz, Konserwatyzm a edukacja demokratyczna, in: Demokracja i edukacja: dylematy, diagnozy, doświadczenia, eds. K. Gawlicz et al., Wrocław 2014, pp. 85-107. 
with the challenges of modern times. Instead, Polish children receive an upbringing that increases xenophobia and nationalism.

Most expert bodies point out that the new core curricula in education advanced by PiS were created in a hurry: the programs are overloaded, underdeveloped, full of factual errors and shortcomings, and anachronistic in form and content. They abandon the integrated model of education in favour of a subjective and fragmentary education. ${ }^{31}$ The changes resulting from the reform favour the selection and segregation of children, and weakens the mechanisms of so-called "vertical mobility" ${ }^{2}$. The reform of education, described by critics in Poland as a "deformity", supports students' passivity. Children are treated as objects, they learn to be docile and subordinated. As noted by Klus-Stańska in the new core curriculum: "(...) the word "respect" appears 51 times, usually as showing respect for others, traditions, symbols, material goods and nature, etc., but "courage" appears only twice, "opposition" not at all, the term "disagree with the opinions" four times, and the word "resistance" is only about the resistance of water and the conductor. Experiencing and discovering one's freedom appears uniquely in concern with the classes on ethics. (...) Children learn to write apologies, but not complaints. It is therefore clear how morally the primary school graduate is to be shaped" ${ }^{33}$. The core curriculum places a decided emphasis on Christian ethics and conservative customs and tradition, with little space for expressing one's own beliefs and criticism. The ideological aspects of upbringing are particularly evident in the classes on "education for family life", which replaced the "sex education" lessons in Poland. The policy of simple solutions applied in the education reform directly affects children, who are formed as passive creatures subjected to control - reproducing mental and symbolic patterns, distant not only from the individual, liberal or multicultural model, but simply irrational. It is to be feared that the new educational policy will not only weaken the competences of Polish children, but will also deepen the contemptuous attitude towards them.

31 This opinion is expressed by, among others, the Committee of Pedagogical Sciences, Committee on Literature Sciences of Polish Academy of Sciences (PAN), opinions of experts from the Polish Teachers' Union (ZNP) and Social Society for Education (Polish STO), the Institute for Advanced Studies and many other national experts bodies and societies.

32 A. Dziemianowicz-Bąk, Polska wojna o szkote, Warsaw 2017.

33 Kaganiec zamiast kaganka? Fak polska szkoła zmienita sie przez cztery lata rzadów PiS, „Dziennik Gazeta Prawna” 2019, https://serwisy.gazetaprawna.pl/edukacja/ artykuly/1431944,jak-polska-szkola-zmienila-sie-przez-cztery-lata-rzadow-pis.html (access 8.02.2021). 


\section{Children in Social Projects}

One of the most popular programs implemented by the PiS government has been the 500 Plus Program, a great project for the recipients but costly for the state budget, which pays parents 500 PLN per month for each child. For many marginalized and poor families, especially in the countryside and smaller towns, it has become a genuine source of financial support. With a little kindness, this program can be treated as a reward for giving birth, and even as a form of a basic income guarantee. This type of direct financial support mechanism for children was also supplemented by the annual school starter kit in the amount of PLN 300, as well as other forms of support that indirectly concern children, e.g. the Toddler Plus Program (a program for the development of childcare institutions), the Mother Plus (various rewards for women who quickly give birth to children), the Mama 4 Plus (a pension scheme for mothers who raise at least four children, but do not earn an income equal to the minimum pension).

The avant-garde and useful nature of the 500 Plus social program and other such projects related to children should not obscure the essence of the matter. Namely, children have again become not only the proverbial tongue in the weight of current politics, but also (together with their families) an instrument for exercising power. Social contributions to children not only make citizens feel a genuine debt of gratitude for such "generosity", but according to universal cultural patterns the gift prompts them to express gratitude. The program can thus be thought of as a form of bribery for the recipients' votes.

Despite the declarations of all opposition politicians that the bill will not be withdrawn, the party in power often scares the public with this prospect, which may indicate the true intentions of the rulers, i.e. treating this direct support as a form of soliciting voters. The 500 PLUS program was also used directly in a dispute over the Constitutional Tribunal. PiS politicians, including Kaczyński himself, maintained that the old composition of the Tribunal needed to be changed because it did not guarantee the successful implementation of this project awaited by citizens. Finally, it should be added that the socio-technically smart 500 Plus Program does not exhaust the issues of social policy towards children, which also includes health, education, and housing. As critics emphasize, when services and the creation of new institutions are at stake, and not only financial instruments (discretionary money transfers beyond the actual control of politicized institutions), PiS's social policy raises many more doubts. ${ }^{34}$

34 M. Polakowski et al., Polityka Spoteczna Rzqdu Prawa i Sprawiedliwości, Warsaw 2017, pp. 8-9, https://library.fes.de/pdf-files/bueros/warschau/13848.pdf (access 8.02.2021). 


\section{Children and Propaganda}

Talented or abused children are best suited for all emotional dealings, as well as for persuasion purposes, to show a rotten reality where the forces of good and childish innocence clash with the evil intentions of eternal enemies and national foes. Using children for propaganda purposes common at least since World War I throughout the world - has strengthened the image of a paternal power exercised by politicians who deal with their gemeinschaft with alleged care, including the images and experiences of heroic and brave children as well as the abandoned, orphaned, exploited, maimed, or disabled. The fate of children was always supposed to not only shock and evoke extreme emotions of rage and helplessness, but also to mobilize others to fight against injustice and violence.

Today in democratic states - as in the times of wars, totalitarianism and military juntas - politicians still exploit children to shape the social imagination, preying on folk naivete and superficial reasoning. Polish politics is also not free from this. PiS politicians like to show up with children, talk publicly about what threatens them, stress their defencelessness and need for protection, as well as dream up the visions of great projects for the sake of both children and their homeland. There are many indications that politicians are doing this consciously and stubbornly for ideological as well as marketing reasons, balancing clumsily on the thin line that separates genuine concern for security or proper public relations from intrusive party and national propaganda.

Let us take few significant examples: in the 2015 election campaign, PiS showed photos of starving Polish children, which, as it turned out, could be bought in an online photo shop. Against the rule forbidding agitation in schools, in 2018 the PiS government distributed information and propaganda materials about the governments' program "Good Start". In New Year's greetings, the Prime Minister appears in a wreath of children, as if they all belonged to him. Family picnics and football matches, where politicians show up in front of children and emphasize the importance they attach to family values, serve similar purposes. In August 2019, in Stalowa Wola, Jarosław Kaczyński, surrounded by children dressed in national costumes, thanked the bishop for defending the idea of family. The bishop was famous for his claims about the threats of the "rainbow plague" (LGBT). Barbara Nowak, the curator of education in the Małopolska region, applied to the Government to award the Medal of the Commission of National Education to the football supporters of the Legia Warsaw Football Club, who not only constitute an important group of PiS voters, but also are known for their shocking propaganda methods 
involving children, which fit into the memory politics of the government fuel hostility and nationalism. For example, during a match Legia fans hung a shocking banner illustrating a German soldier putting a gun to the head of a little boy. The banner read: "During the Warsaw uprising Germans killed 160,000 people. Thousands of them were children". In defence of the new memory politics, President Andrzej Duda said: “(...) today the children and grandchildren of the traitors of the Republic, who fought to maintain the Soviet domination over Poland, occupy many prominent positions in various places". ${ }^{35}$ Although this phrase applies to people who are presumably already adults and is only an unjustified presumption, it corresponds to the above-discussed belief that there are ideologically and morally distorted children, or simply "badly born" ones. This view underlies the reform of education, both in its institutional and curricular dimensions.

It is difficult to understand the nature of this right-wing populist "care" in the context of their acquiescence to children's participation in bloody hunts, or their dramatic indifference towards the psychiatric protection of children in Poland, or their passivity in face of regularly disclosed cases of paedophilia in the Polish Church. Despite their declared willingness to defend the authority of the family, one gets the impression that right wing populists are interfering with the autonomy of upbringing, shaping characters, and even influencing the models of intimate life.

\section{Conclusions}

In this paper we have tried to show how children and their problems have been used over the last few years in various areas of policy by PiS the party in power in Poland. It can be argued that the presence of these issues in public space is something natural and obvious, especially in the politics of the European right. Any economic, educational, environmental, cultural, family, health, safety, etc. policy always affects children to some extent, and it would be irresponsible to ignore them. ${ }^{36}$ Children have always been a symbol of hope, and as such have been used in political propaganda in Poland before. On the other hand, today we are dealing not

${ }_{35}$ Prezydent w TVP Historia: Dzieci $i$ wnuki zdrajców Rzeczypospolitej zajmujq eksponowane stanowiska, „Gazeta Wyborcza” 30.04.2017, https://wyborcza. pl/7,75398,21751420,prezydent-w-tvp-historia-spor-o-zolnierzy-wykletych-to-takze. html (access 8.02.2021).

36 S.A. Sherr, Scenes from the Political Playground: An Analysis of the Symbolic Use of Children in Presidential Campaign Advertising, "Political Communication", no. 16(1)/1999, pp. 45-59, DOI: https://doi.org/10.1080/105846099198767. 
only with ordinary moral conservatism, but rather with populism, because this issue and the way it is used reveal almost all the most characteristic features of populist politics and discourse, which quite freely exploit values from often different ideological orders.

First, children are used to increase social divisions. They are presented as victims of the post-communist legacy; the unjust reforms of the transition period; and the liberal changes that brought about Poland's membership in the European Union. Secondly, children are the object of a national-conservative politics that, through schools and new curricula, indoctrinate them within a new memory politics and conservative moral principles. Third, children are used to justify key reforms in the areas of education, social security, immigration policy, etc., following the message that the state institutions that functioned so far were only nominally democratic and, in fact, did not fulfil their mission. Fourth, children, as a symbolic projection of the nation's future and the main concern of all the people in dealing with their problems, are used to point out all kinds of social, ideological, historical, institutional etc. enemies. Fifth, children are therefore an instrument for manifesting otherness, which - per analogiam to defenceless, innocent and suffering people - is constantly threatened. Sixth, according to Gramsci and Bourdieu, children are in effect used to reproduce political and social hegemony. Seventh, children are treated instrumentally not only as the subject of politics, but in an anthropological dimension as beings devoid of subjectivity and all agency. This is not only an outdated way of thinking about children, but it also stands in conflict with the latest research in the field of children's anthropology.

Using children in politics and propaganda, although practiced for a long time, currently remains at least morally ambiguous and requires continued research and verification of the boundary that separates the public good from harmful manipulations with respect to their participation. Such research seems to be particularly important in the present times, marked by an increasingly visible crisis of liberal democracies, a new wave of populist and reactionary movements (not only in Poland, but throughout the region and the world), as well as in the face of increasingly dramatic questions about the prospects of societies that will be guided someday by our children. 


\section{References}

Akkerman T., Populism and Democracy: Challenge or Pathology?, "Acta Politica", no. 38/2003, DOI: https://doi.org/10.1057/palgrave.ap.5500021. Amnesty International, Portes ouvertes sur l'avenir. Non à la ségrégation des enfants Roms dans les écoles slovaques, 2010, https://www.amnesty. org/download/Documents/EUR720042010FRENCH.PDF (access 8.02.2021).

Ariès P., L'Enfant et la vie familiale sous l'Ancien Régime, Sciences Po University Press, Paris 1975 ( $1^{\text {re }}$ éd. 1960), DOI: https://doi.org/ 10.2307/3319068.

Benedict R., Continuities and discontinuities in cultural conditioning, "Psychiatry", no. 1/1938, DOI: https://doi.org/10.1080/00332747.1938. 11022182.

Billout M., Rapport d'information fait au nom de la commission des affaires européennes sur l'intégration des roms: un défi pour l'union européenne et ses états membres, 2012, https://www.senat.fr/rap/r12199/r12-199_mono.html (access 8.02.2021).

Bugaric B., Populism, Liberal Democracy, and the Rule of Law in Central and Eastern Europe, "Communist and Post-Communist Studies", no. 41(2)/2008, DOI: https://doi.org/10.1016/j.postcomstud.2008.03.006.

Bunt kobiet. Czarne Protesty i Strajki Kobiet, eds. E. Korolczuk et al., ECS, Gdańsk 2018.

Dagiel D., Kowalik-Olubińska, D., Bycie dziecka w Polsce 'dobrej zmiany' - między Konwencja o Prawach Dziecka a rzeczywistościa, "Problemy Wczesnej Edukacji”, no. 4(43)/2018, DOI: https://doi.org/10.26881/ pwe.2018.43.11.

Dejneka P., Populizm a sfera publiczna, Czy populizm zrewitalizuje sfere publicznq w Europie, PWN, Warszawa 2019.

Dziemianowicz-Bąk A., Polska wojna o szkote, Institute of Advanced Studies, Warsaw 2017.

Exposé of Prime Minister Beaty Szydło of 2015, https://www.gov.pl/web/ premier/stenogram-expos-premier-beaty-szydlo (access 15.04.2021).

Gidron N., Bonikowski B., Varieties of Populism: Literature Review and Research Agenda, „Working Paper Series, Weatherhead Center for International Affairs", No. 13-0004/2013, DOI: http://dx.doi. org/10.2139/ssrn. 2459387.

Interview with Jarosław Kaczyński, Kaczyński: Polska minus? Będzie sie demoralizowato dzieci, „Rzeczpospolita” 2019, https://www. rp.pl/LGBT/191009763-Kaczynski-Polska-minus-Bedzie-siedemoralizowalo-dzieci.html (access 5.02.2021). 
Kaganiec zamiast kaganka? Fak polska szkota zmienita sie przez cztery lata rzqdów PiS, „Dziennik Gazeta Prawna”, 27.09.2019, https://serwisy. gazetaprawna.pl/edukacja/artykuly/1431944,jak-polska-szkolazmienila-sie-przez-cztery-lata-rzadow-pis.html (access 8.02.2021).

Kirsi P.K., Häkli J., Are There Politics in Childhood?, "Space and Polity", no. 15(1)/2011, DOI: https://doi.org/10.1080/13562576.2011.567897.

La Fontaine J., An anthropological perspective on children, in: Children of Social Worlds. eds. M. Richards, P. Light, Polity Press, Cambridge MA. 1986.

Laclau E., Populism: What's in a Name?, in: Populism and the Mirror of Democracy, ed. F. Panizza, Verso, London 2005.

Lubbock J., The origin of civilisation and the primitive condition of Man, Longmans, Green and Co. New York, Bombay and Calcutta 1912.

Mead M., Coming of Age in Samoa, William Morrow \& Co., New York 1928.

Mény Y., Surel Y., The Constitutive Ambiguity of Populism, in: Democracies and the Populist Challenge, eds. Y. Mény, Y. Surel, Palgrave Macmillan, London 2002, DOI: https://doi.org/10.1057/9781403920072_1.

Michalak M., Letter to Prime Minister. Document nr GA8.422.10.2018. BS.

Michalak M., Letter to Prime Minister. Postawy rasistowskie i ksenofobiczne się nasilają. Jak temu przeciwdziałać? Rzecznik pisze do premiera Morawieckiego i ministra Ziobry. Document $\mathrm{nr}$ XI.518.5.2018.

Mudde C., Kaltwasser, R.C., Working Paper: Voices Of The Peoples: Populism in Europe And Latin America Compared, 2011, https://kellogg.nd.edu/ sites/default/files/old_files/documents/378_0.pdf (access 5.02.2021).

Mudde C., The Populist Zeitgeist, "Government and Opposition", no. 39(4)/2004, DOI: https://doi.org/10.1111/j.1477-7053.2004.00135.x.

Polakowski M., et al., Polityka Spoteczna Rzqdu Prawa i Sprawiedliwości, Friedrich-Ebert-Stiftung, Warsaw 2017, https://library.fes.de/pdf-files/ bueros/warschau/13848.pdf (access 8.02.2021).

Populism, Memory and Minority Rights: Central Eastern European Issues in Global Perspective, ed. A.-M. Bíró, BRILL, Boston 2018, DOI: https:// doi.org/10.1163/9789004386426.

Prezydent w TVP Historia: Dzieci i wnuki zdrajców Rzeczypospolitej zajmuja eksponowane stanowiska, „Gazeta Wyborcza” 30.04.2017, https:// wyborcza.pl/7,75398,21751420,prezydent-w-tvp-historia-spor-ozolnierzy-wykletych-to-takze.html (access 8.02.2021).

Program Prawa i Sprawiedliwości. Polski Model Państwa Dobrobytu, 2019. http://pis.org.pl/files/Program_PIS_2019.pdf (access 5.02.2021). 
Rawls J., Theory of fustice (revised edition), The Belknap Press of Harvard University Press, Cambridge MA. 1999.

Sherr S.A., Scenes from the Political Playground: An Analysis of the Symbolic Use of Children in Presidential Campaign Advertising, "Political Communication", no. 16(1)/1999, DOI: https://doi.org/10.1080/105846 099198767.

Skelton T., Taking young people as political actors seriously: opening the borders of political geography, "Area”, no. 42/2010, DOI: https://doi.org/10.1111/ j.1475-4762.2009.00891.x.

Stewart M., The Gypsy 'menace': Populism and the New Anti-Gypsy Politics, Hurst Publishers, London 2012.

Such E., Walker R., Young citizens or policy objects? Children in the 'rights and responsibilities' debate, "Journal of Social Policy", no. 34(1)/2005, DOI: https://doi.org/10.1017/S0047279404008256.

Szafrańska M., Penalny populizm a media, Wydawnictwo Uniwersytetu Jagiellońskiego, Kraków 2015.

Taggart P., Populism and the pathology of representative politics, in: Democracies and the populist challenge, eds. Y. Mény, Y. Surel, Palgrave Basingstoke 2002, DOI: https://doi.org/10.1057/9781403920072_4.

Taylor E.B., Primitive Culture, John Murray, London 1903.

Tismăneanu V., Fantasies of Salvation: Democracy, Nationalism and Myth in Post-Communist Europe, Princeton University Press, Princeton 1998, DOI https://doi.org/10.1515/9781400822508.

To poczatek nowej epoki kulturowej. Wrogiej feminizmowi $i$ kobietom, wrogiej cztonkom spoteczności LGBT $i$ mniejszościom, „Gazeta Wyborcza", 17.09.2018, https://www.wysokieobcasy.pl/wysokieobcasy/7,163229,23932327,to-poczatek-nowej-epoki-kulturowejwrogiej-feminizmowi-i-kobietom.html (access 8.02.2021).

Tokarz T., Konserwatyzm a edukacja demokratyczna, in: Demokracja $i$ edukacja: dylematy, diagnozy, doświadczenia, eds. K. Gawlicz et al., Wydawnictwo Naukowe Dolnośląskiej Szkoły Wyższej, Wrocław 2014.

White S., Choudhury, S., The politics of child participation in international development: the dilemma of agency, "The European Journal of Development Research", no. 19(4)/2007, DOI: https://doi.org/10.1080/ 09578810701667508.

Wpolityce.pl, 23.03.2019, https://wpolityce.pl/polityka/439323-prezespis-trzeba-bronic-polskiej-rodziny (access 5.02.2021). 